\title{
ESPACIO URBANO Y GUERRA CIVIL EN LUCIÉRNAGAS DE ANA MARÍA MATUTE
}

\author{
Marisa SOTELO VÁZQUEZ
}

Universitat de Barcelona.

\section{RESUMEN}

El artículo, tras la clasificación de Luciérnagas como novela de aprendizaje, pretende demostrar la función relevante que el espacio urbano ligado a un tiempo concreto, verdadero cronotopos, desempeña en la novela. El análisis demuestra que el espacio es tan potente que en algunos momentos desplaza la atención del personaje, convirtiéndose en verdadero protagonista del relato. La visión caótica y apocalíptica de la ciudad de Barcelona es el escenario de Luciérnagas pero es también metáfora, metonimia y símbolo de los personajes

Palabras clave: Ana María Matute, Luciérnagas, bildungsroman, espacio urbano, guerra civil.

\section{ABSTRACT}

This paper, after clasifying Luciérnagas as a «bildungsroman» or coming-of-age story, wants to prove the relevant function that plays in the novel an urban space tied to a concrete time, its chronotope. Our analysis shows that the element of space is so strong that sometimes displaces our attention to the main character, and therefore it becomes the real protagonist of the story. The chaotic and apocalyptic view of Barcelona is the stage of Luciérnagas, but also becomes its characters' metaphor, metonymy and symbol.

Keywords: Ana María Matute, Luciérnagas, Bildungsroman, Urban Space, Spanish Civil War 


\section{LUCIÉRNAGAS: BARCELONA 1935-1939, CRONOTOPO DE UNA NOVELA DE FORMACIÓN}

En 1955 Ana María Matute publica en la barcelonesa editorial Éxito En esta tierra, reescritura de la primera versión de Las Luciérnagas, que había sido prohibida unos años antes por la censura ${ }^{1}$. Dicha novela, finalista del premio Nadal de 1949, convocatoria en la que resultó ganadora la espléndida novela de Suárez Carreño Las últimas horas, indudablemente preparaba el camino a Primera memoria, premio Nadal de 1959, novela con la que presenta notables similitudes temáticas ${ }^{2}$. En 1993, tras una cuidada y extensa revisión de la autora, reaparece la versión primitiva, en la que entre otras cosas recuperó el título original de la novela Luciérnagas, suprimiendo el artículo inicial. Una vez más en la trayectoria narrativa de la novelista barcelonesa estamos ante una obra que trata de la corrupción de la inocencia, del tránsito de la adolescencia a la madurez, es decir estamos ante una novela de formación. La evolución psicológica de Sol Roda, una adolescente de familia acomodada, que ve cómo su entorno familiar y social se descompone y destruye bruscamente con el estallido de la guerra civil.

Luciérnagas, ambientada en Barcelona y con una cronología muy precisa, comienzos del verano de 1935 al 26 de enero de 1939, refleja la transformación personal y existencial de la adolescente Sol y los demás protagonistas de la historia, su hermano Eduardo y los amigos de éste, Chano y los hermanos Daniel, Pablo y Cristián, a la vez que se describe con exactitud la metamorfosis del espacio urbano que habitan. Sol pertenece a una familia burguesa del ensanche barcelonés que, tras el asesinato de su padre al comienzo de la contienda bélica, ve como todo su mundo -hasta entonces perfecto y feliz-se fractura y se descompone ante esa sensación nueva de inseguridad y miedo que se adhiere a su vida como, tras los bombardeos, el polvo de los escombros se pegaba a la piel:

1. Sobre los argumentos de la censura véase el prólogo al segundo volumen de las Obras Completas en el que Ana María Matute reproduce literalmente el informe del censor, del que entresacamos las siguientes palabras: "Considerando lo expuesto, el lector que suscribe opina que no debe autorizarse la obra, pues, intrínsecamente, resulta destructora de los valores humanos y religiosos esenciales. No se hace especial mención de páginas, porque es toda la novela y su fondo (más que los pasajes crudos) los que aparecen recusables» (Matute, 1971: 9)

2. En ambas novelas el conflicto bélico está muy presente como escenario de la acción narrativa, así como también en ambas la protagonista es una adolescente, Sol en Luciérnagas y Matia en Primera memoria, que ven destruido bruscamente el mundo feliz de su infancia. Cf. Marisa Sotelo Vázquez (1999: 172). 
Así, el tiempo pasaba y Elena seguía en su esperanza de una inmediata paz. Al oírla Sol experimentaba una angustia honda, terrible. La abrazaba y procuraba consolarla como a una niña pequeña. Dentro de ella, una voz le decía que aquello era sólo el principio de un tiempo, largo y desconocido. Que el mundo que añoraba su madre estaba definitivamente muerto. Algo en su vida había terminado para siempre.

Y llegaron unos días largos, royendo el tiempo con dura indiferencia. Por primera vez la palabra hambre tuvo sentido en aquella casa.

Algunas noches, Sol no conseguía dormirse. Se levantaba, iba hacia la ventana y miraba a la noche, con las manos abiertas sobre el cristal. Llegó un invierno mojado, brillante aún en la calle, que nadie tenía tiempo de limpiar. Continuamente rechinaban las ruedas de los camiones, llevándose hombres a la guerra. Sol no sabía que pretendían defender aquellos hombres. Sentía una honda indignación por lo que era su propia vida, su juventud. No había derecho -pensaba- a ser engañado año tras año y un buen día ser arrojado de frente contra aquella verdad. No había derecho a que la verdad fuese el miedo y la resignación. No se podían tener dieciocho años para ir escondiéndose, escapándose a esas balas perdidas en las esquinas, alistándose a la humillación de una cola para poder comer. El temor, siempre el temor. Amanecían unos aviones o unos barcos y dejaban el suelo empapado de muerte. La verdad no debía ser el hambre, la agresión y la muerte. No podía serlo (Matute: 1993: $51-52)^{3}$.

Este es el tono absolutamente desolado que domina todo el discurso de $\mathrm{Lu}$ ciérnagas, presidida por la admonición bíblica: «Verás de frente la tierra que yo daré a los hijos de Israel: Y no entrarás en ella», palabras del Deuteronomio ${ }^{4}$, que en el curso del relato aluden simbólicamente al espacio urbano como tierra prometida y cobran todo su significado al final de la novela con la muerte violenta en las laderas del Tibidabo de Cristián, el joven del que se ha enamorado Sol y del que está esperando un hijo. La tierra prometida es la ciudad, Barcelona, que ambos jóvenes contemplan a sus pies y que en el caso de Cristián una muerte fortuita y violenta le impedirá volver a ella.

Estructurada en tres partes, Luciérnagas podría calificarse de novela lírica de aprendizaje ${ }^{5}$, es decir, con un diseño que se corresponde básicamente

3. Todas las citas de la novela remiten a esta edición, Barcelona, Destino, Áncora y Delfín, $\mathrm{n}^{\circ} 710,1993$, y a partir de aquí sólo se indicará la página entre paréntesis.

4. La referencia exacta es: «Esta es la tierra que prometí a Abrahán, a Isaac y a Jacob, diciéndoles: Se la daré a tu descendencia. Te la he hecho ver con tus propios ojos, pero no entrarás en ella» (Deuteronomio, 34: 4)

5. Las relaciones entre ambos géneros han sido señaladas por Freedman (1972), Darío Villanueva (1983) y Ricardo Gullón (1984). Valgan como ejemplo las siguientes palabras de Darío Villanueva: «Porque la novela lírica se identifica en gran medida con una singular manifestación del Bildungsroman o novela de aprendizaje: el relato autobiográfico 
con el esquema iniciático propio de la novela de formación o bildungsroman, que J. Campbell (1980:53-223) plantea en tres fases -partida, iniciación y regreso- más un lenguaje narrativo que se aproxima mucho al lenguaje poético, en el que abundan metonimias, metáforas, comparaciones, símbolos y rítmicas repeticiones semánticas y sintácticas. Todos estos recursos retóricos son una constante en la producción narrativa de Ana María Matute desde Los Abel (1947) hasta Paraíso inhabitado (2008) pasando por la faulkneriana Los hijos muertos (1958), Primera memoria (1959), Olvidado rey Gudú (1996), El paraíso inhabitado (2008) y un buen número de cuentos espléndidos, como la poemática colección Los niños tontos (1956), que son un buen ejemplo de la formulación de Hermann Hesse: «La novela es una lírica disfrazada, un rótulo prestado para que las experimentaciones de los espíritus poéticos expresen sus sentimientos del yo y del mundo» (Freedman, 1972: 7).

El 28 de enero de 1956 desde las columnas de la barcelonesa revista Destino Antonio Vilanova, con su habitual agudeza crítica, subrayaba el aspecto poemático de En esta tierra, evidente en el tratamiento de la protagonista, pero sobre todo en el estilo, que dotaba a la narración de un ritmo creciente desde la primera a la última página:

Ana María Matute posee una mágica y sobrecogedora intuición de la vida, y no solo de la vida íntima de su heroína, a la que retrata en el difícil tránsito de la vaga feminidad adolescente a la plenitud de mujer, sino de la vida cotidiana y vulgar en todo cuanto atañe a la eterna y doliente condición humana. Esta prodigiosa intuición de la vida, este conocimiento intuitivo de las cosas y los seres, de los sentimientos y de las pasiones humanas, va acompañado de una extraordinaria fuerza expresiva que caracteriza su estilo peculiarísimo, cuya profusión de imágenes le confiere una jugosa plasticidad y una honda sugestión poética (Vilanova, 1995: 300).

Prodigiosa intuición de la vida y extraordinaria fuerza expresiva en esta novela de aprendizaje que, más allá de las peculiaridades señaladas por Bajtín (1982) novela de educación y por Moretti (1999) novela de formación, mantiene unas constantes en su poética, que conciernen sobre todo a la modalización, el tratamiento espacio-temporal, además de determinadas características temáticas -como el sustrato autobiográfico- y la estructura abierta, que han sido sintetizadas por diversos estudiosos ${ }^{6}$, que nos servirán aquí como marco referencial pero en las que no vamos a entrar porque no competen al análisis que nos proponemos.

de la constitución de una sensibilidad artística, personificada en un personaje emblemático, alter ego del autor» (Prólogo a La novela lírica I, 1983:14).

6. Cf. Rodríguez Fontela, Ma Ángeles, La novela de autoformación (1996). 
Conviene, sin embargo, comprobar hasta qué punto la estructura de Luciérnagas es la propuesta por los teóricos del bildungsroman. En este sentido la partida corresponde a los seis primeros capítulos (pp. 11-138), presentación de la protagonista, que focaliza el relato, y del espacio que habita, así como el estallido de la guerra y el asesinato de su padre, son sucesivas pruebas que marcan también el inicio simultáneo de una transformación vital y espacial; la segunda parte, más extensa, formada por nueve capítulos (pp.141-272), corresponde al período de iniciación y honda transformación psicológica de la protagonista en un largo peregrinaje por la ciudad bajo la continua amenaza de las bombas; y la tercera, mucho más breve, los tres últimos capítulos (pp.275-312), con el regreso de Sol a su casa, tras un largo periplo urbano que la ha llevado a vivir situaciones límite, como el descubrimiento de los barrios bajos, la muerte de los amigos, un trágico bombardeo, el hambre, la lucha por la supervivencia y el paso por la cárcel, en definitiva, un cúmulo de experiencias vitales que la han cambiado profundamente. En el transcurso de este proceso iniciático Sol ha realizado un viaje doble -metafórico, hacia sí misma, y real, por diferentes barrios de la ciudad-, y el resultado es una honda transformación, que podría sintetizarse entre estos dos hitos, el comienzo del viaje iniciático de la adolescente, que abandona feliz e ignorante del porvenir el pensionado de Saint-Paul, el último curso antes de la contienda bélica: «Así, con dieciséis años inquietos, ignorantes, y un extraño acordeón de libros mal atados -en el que parecía empaquetar toda su infancia-, ojeando pensativamente su cuaderno escolar, le sorprendió el estallido de la guerra» (37), y el final, la joven convertida en mujer, que regresa a su casa tras la experiencia traumática de la guerra pero fortalecida por el descubrimiento del amor y la ilusión del hijo que espera. La transformación se ha consumado, la diferencia entre la protagonista de la partida y la del regreso es evidente, ahora Sol Roda es plenamente consciente de que ya nada volverá a ser como antes, por ello ante las palabras de su madre que se aferra al pasado como tabla de naufrago:

- iEste mundo horrible se acaba, gracias a Dios! Lo sé, Sol, yo lo sé. Todos lo saben... Ahora, todo volverá a ser como antes. Volveremos a vivir los tres reunidos como entonces. Sin miedo, sin hambre... Con nuestras creencias, con nuestras costumbres, con nuestras cosas, con nuestros muertos queridos... (290),

Sol, consciente del profundo cambio operado en sí misma y también en la realidad que la rodea, responde:

-No para mí, no para mí...-dijo, con voz apenas perceptible-. Ya nada puede ser como antes para mí. Yo no soy la de antes, ¿comprendes? Soy yo la que no puede volver a aquel tiempo $[\ldots]$ 
Soy otra, la vida me ha hecho distinta, y no puede importarme el no ser como antes (291).

Entre estos dos momentos, que se corresponden con la cronología de la historia y que evidencian la honda transformación de la protagonista, se desarrolla la narración en unas coordenadas espacio temporales que son indisociables de la evolución psicológica de la misma. Con un evidente sustrato autobiográfico Ana $\mathrm{M}^{\mathrm{a}}$ Matute traza una visión alucinante de la ciudad de Barcelona, sumida en el caos, el hambre y la miseria, teñida de sangre y venganzas. La ciudad, los diferentes escenarios urbanos, que son también escenarios de la memoria de la narradora, Pedralbes, el Ensanche, la calle Muntaner, la plaza Universidad, el barrio gótico, la Vía Layetana, la Barceloneta desembocando en el mar, las laderas del Tibidabo, sembradas de barracas de refugiados con la ciudad a sus pies, son junto a la reflexión sobre el paso del tiempo y la evocación de la infancia feliz, truncada por los sucesos bélicos, los verdaderos motivos temáticos que se imponen con extraordinaria fuerza poética a los ojos y la sensibilidad del lector.

Centraremos el análisis en la dimensión espacial, que como en tantas novelas de iniciación cobra alternativamente una dimensión metonímica, metafórica o simbólica en estrecha correlación con la experiencia que vive la protagonista. De manera que podríamos decir, tal como sostiene Ricardo Gullón que «el espacio lo crea el personaje. [...] esa creación revela su carácter y es un modo (el espacio) de figuración simbólica (1980: 24), y en consecuencia puede establecerse una relación de reciprocidad e incluso de simbiosis entre el espacio y la protagonista. Veámoslo a través del análisis del discurso espacial que acompaña el proceso iniciático de Sol.

\section{LA PARTIDA: DE LA CIUDAD SOÑADA A LA CIUDAD REAL}

En la primera parte de la novela la Barcelona roja se despliega ante la mirada inocente y atónita de la adolescente Sol, que no acierta a entender el significado de la palabra revolución oída a todas horas a su alrededor. Sus románticos sueños en el internado de Saint-Paul «creyéndose el centro del mundo. Pero el mundo resultó distinto a todo lo ella aprendió a temer o amar» (11), así como su ciudad imaginada tan poco parecida a la real:

Dentro del pupitre había formado, con cuadernos y libros una ciudad maravillosamente complicada. Pero ella nada sabía de las ciudades, ni siquiera conocía aquella en que había nacido. Qué difícil de imaginar, entonces, que era posible reducir a escombros parte de una ciudad, en unas horas «(12),

se desvanecen ante la cruda realidad que observa desde las ventanas de su casa en los días inmediatamente posteriores al alzamiento nacional. El confortable 
espacio doméstico, verdadero refugio de su familia y de María ${ }^{7}$, la fiel criada, se transforma radicalmente ante la imperiosa necesidad de sobrevivir tras el asesinato del padre, el industrial Luis Roda. A partir de este suceso crucial que trastorna la vida de la protagonista se inicia un doloroso proceso de maduración psicológica que se acompasa a la progresiva transformación del espacio tanto en su dimensión doméstica, familiar e íntima como en su dimensión urbana y social. Sol, aunque de forma un tanto vaga e imprecisa, intuye que el estallido de la guerra y su correlato de violencia y muerte va a suponer irremisiblemente el final de todo un mundo, es decir, el final de un tiempo y un espacio vital: «Dentro de ella [Sol] una voz le decía que aquello era sólo el principio de un tiempo, largo y desconocido. Que el mundo que añoraba su madre estaba definitivamente muerto. Algo en su vida había terminado para siempre» (47).

La protagonista no se engaña, y el espacio se revelará decisivo en su personal toma de conciencia, pues la narradora evidenciará a través de la descripción del comienzo de la guerra, de las constantes movilizaciones, de los continuos registros del domicilio familiar, la pérdida de intimidad:

La ventana, como todas las de la casa, estaba abierta de par en par, en cumplimiento de una orden de la Comisaría de orden Público para impedir se disparase desde dentro.

El resol arrancaba un brillo exasperado a las paredes. Un leve sudor humedecía las sienes de Sol. De vez en cuando, su corazón parecía detenerse. Cortante, brusco, llegaba el redoble de alguna ametralladora, como el rebote de un juguete siniestro, hasta las paredes blancas de aquel cuarto, que se diría sólo contenía una paz tierna, ignorante, de colegiala (38).

Espacio y tiempo fundidos en una continuidad indisoluble, como escenario de la progresiva destrucción tanto del espacio urbano como del doméstico y familiar:

Los días continuaron. Continuaban, uno tras otro, como sus vidas. Sol, desde la terraza, vio arder los templos, la ciudad emborronada por grandes resplandores rojizos y el polvo negruzco del hollín; las nubes cruzaban el cielo, sobre la ciudad, hacia otros países.

7. Este personaje es una constante en las novelas de Ana $\mathrm{M}^{\mathrm{a}}$ Matute y tiene que ver con un dato autobiográfico, la tata Anastasia que cuidó de la autora en la infancia es María en Luciérnagas, Mauricia en Primera Memoria (1959) y la tata de El paraíso inhabitado (2008), tres de los relatos en que el sustrato autobiográfico es más importante, al igual que dos de ellas se ambientan en la guerra civil, experiencia que dejó honda huella en la novelista.

Anales, 24, 2012, pp. 319-336 
Dos veces aún, después de aquella noche en que se llevaron a su padre, llegaron patrullas de hombres y registraron el piso. Irrumpían con violencia y golpeaban los muebles con la culata de los fusiles (44).

Este espacio familiar, poblado de objetos y recuerdos, va a ser borrado sin compasión por las patrullas de registro o simplemente la familia tendrá que deshacerse de los objetos de más valor para poder sobrevivir a la amenaza del hambre mientras contempla impotente cómo se instalan unas milicianas en su propia casa:

En casa el piso parecía barrido por un viento despiadado. Cosas y cosas queridas se echaban de menos. Su madre vendió lámparas de cristal y bronce. Los objetos de metal codiciado desaparecieron -entre registros y ventas, los cuadros y objetos de adorno desaparecieron-, el suelo rayado por los clavos de las botas y los bayonetazos de los milicianos, la desolación material, en fin, era aún soportable (53).

Y si todas estas pérdidas materiales son dolorosamente soportables no lo será el hambre, que se vuelve cada vez más acuciante y es el móvil fundamental en la transformación del espacio:

Por entonces empezaba a hacerse preciso salir fuera de la ciudad, a los pueblecillos, en busca de alimentos, conseguidos casi al asalto. La ciudad era pobre, estaba despojada. El hambre iba dejando su sombra viscosa, más ancha a medida que pasaban los días, como una gran mancha siniestra (49)

El hambre, esa sensación hasta entonces desconocida para la familia acomodada de la protagonista, trae consigo otra transformación del espacio urbano con la presencia de las colas de racionamiento, que obligan a Sol a permanecer «largas horas en las calles para lograr un panecillo o un trozo de jabón, en lucha angustiosa, desmesurada para ir existiendo, simplemente existiendo, y arrastrando los pies» (53). Todas estas carencias agudizan el ingenio de Eduardo, el hermano de Sol, pues mientras ésta trabaja en la Academia de su antiguo profesor Ramón Boloix, él contempla «la ciudad con extraña avidez» (45) y decide asociarse a una pandilla de muchachos, Chano, un pillete, que vive de sus hurtos en una barraca en las laderas del Tibidabo y Daniel, que tiene dos hermanos mayores, Pablo, joven anarquista, y Cristián ${ }^{8}$, opuesto a Pablo en ideas pero que siempre ha dependido de él. Una vez formado el

8. Sobre estos dos personajes y su función en el relato me parece muy atinado el juicio de Vilanova cuando escribe: «Ana María Matute ha intentado explicar las circunstancias familiares, sociales y humanas que desde su niñez triste, ensombrecida por la estrechez y la miseria, impulsaron a Pablo Barral, hombre generoso y bueno que sacrificó su vida entera a su padre y sus hermanos, a profesar, en su rabioso anhelo de justicia, un culto ciego de la violencia y el odio». No obstante el crítico considera que el perfil del personaje a pesar de su autenticidad resulta falso, pero aún así «eclipsa por completo la 
grupo, Sol acompaña a su hermano en un peregrinaje urbano, que le permite descubrir otros barrios de la ciudad, hasta entonces totalmente ignorados:

Entraron por la calle del Buensuceso, hasta la plaza y se arrimaron al mostrador de mármol de un bar viejo y destartalado. Fuera había dos mesas y butacas de mimbre donde se sentaban milicianos y soldados. Enfrente, una iglesia, convertida en cuartel (87).

La fuerza del espacio es tan potente que en algunos momentos acaba desplazando la importancia del personaje. La personificación y la metonimia son los dos recursos fundamentales de que se sirve la narradora para calificar ese espacio urbano que se va transformando inexorablemente ante los ojos de la protagonista. La ciudad «despojada», «herida», «apagada» es imagen de la situación de sus habitantes, hasta desembocar como éstos en un silencio cruel y opresor:

Pasó el tiempo. Día tras día, la ciudad fue apagándose. Un nuevo aspecto, sucio y miserable, se descubría ante los ojos de Eduardo. Una ciudad despojada, herida. Las tiendas pequeñas, vacías, los almacenes cerrados, los hombres en el frente. Ya no se veían desfilar puño en alto a las mujeres vestidas de soldado... Una sombra triste, húmeda, iba cubriendo la ciudad. Los edificios oficiales tenían ahora un aire siniestro. Las matanzas acrecían, pero sistematizadas, bajo un barniz de legalidad. No se traslucía una gota de sangre, un incendio. Un silencio cruel, opresor. Como producido por golpes sin ruido. (89).

En este deambular de los dos hermanos por el espacio urbano, dos son las experiencias críticas que van a vivir en esta parte de la novela. La primera es la visita de Sol y Eduardo a la buhardilla de Daniel, enfermo de tuberculosis, que vive en una calle oscura que desemboca en el Paseo de Colón. Este suceso supone para Sol el descubrimiento de otra ciudad hasta entonces desconocida, con otras formas de vida, así como también el descubrimiento de la miseria, la enfermedad y la muerte. La descripción por planos casi cinematográficos avanza desde la panorámica exterior a la del mísero cuartucho donde yace enfermo Daniel:

La calle era angosta, sin luz, y desembocaba en el Paseo de Colón. Eduardo reconoció el salobre del mar frío y mohoso, y lo aspiró con incierta melancolía. Los muros de las casas, altos y sombríos, deslizaban el cielo sobre sus cabezas, como un río negro (96)

La escalera de la casa donde vivía Daniel era angosta, de peldaños altos y estrechos. (97)

artificiosa figura de su hermano Cristián, aunque sea éste quien despierte el amor en el alma apasionada y ardiente de la desdichada Sol» (Vilanova, 1995: 301). 
La buhardilla [...] Era una pieza pequeña con una ventana al patio. En una cama de hierro negro yacía Daniel, vestido con una bufanda al cuello. La ventana estaba cerrada. Un olor peculiar y la espesura de la atmósfera daban a entender que aquella pieza no era ventilada con frecuencia. En las paredes, se abrían grandes manchas de humedad nerveadas por grietas profundas. (98).

La segunda experiencia decisiva será la visita también junto a su hermano Eduardo a las barracas-refugio en las afueras de la ciudad, donde éste se reúne con sus amigos de correrías y hurtos: «La llevó ciudad arriba, hacia el Tibidabo. A medida que se acercaban a la montaña, la ciudad, tras ellos, parecía huir rosadamente, dulcemente, como si no existiera la guerra» (76).

En una de esas barracas guardaban el botín de sus correrías y vivía Chano, verdadero pilluelo sin familia y sin afectos, con ecos del golfo barojiano de La busca. La simbiosis entre el espacio y este personaje es absoluta. El pobre muchacho vive en condiciones infrahumanas, como un animal, al margen de la ciudad, en un espacio miserable, construido por el mismo a base de detritus urbanos, como en los extrarradios del Madrid de Tiempo de silencio:

Le explicó, entonces, que tenían su guarida, con provisiones, en una barraca de la ladera de la montaña. En ella, además de ser el punto de reunión vivía un muchacho llamado Chano. En improvisadas cuevas, en el Tibidabo vivían gentes que huían de los bombardeos, anidadas como animales, resguardándose con jirones de estera y cañas secas. (77)

La descripción de este espacio marginal como un paisaje polvoriento y calcinado es muy gráfica:

Nunca antes pisó aquellos parajes. La hierba aparecía rapada y seca, y la tierra polvorienta, muy pisoteada. La silueta de las montañas despedía una extraña luminosidad lechosa. Muchos de los árboles fueron talados para hacer leña [...] La barraca era pequeña y frágil, construida con ladrillos viejos, latas oxidadas y cañas. Eduardo apartó los maderos que protegían el agujero de la puerta, y entraron. Olía a suciedad, a frío, a hierbas mustias. En una esquina un colchón, mugriento y aplastado, despedía un hedor dulzón (77).

$\mathrm{Y}$ al pie de las barracas-madrigueras la ciudad que al igual que sus habitantes se va degradando por los efectos de la guerra:

La ciudad era ahora una ciudad distinta. Por las calles, antes limpias, se amontonaba la basura. Las gentes iban mal vestidas [...] Los edificios que creyó seguros, inconmovibles, parecían llenarse de un temblor irreal, fantástico. En los balcones, grandes carteles y banderas, hombres con fusiles y ametralladoras. Por las calles, hombres vestidos con mono azul o con el torso desnudo, con rojos pañuelos al cuello desfilaban puño en alto. Camiones y coches, abarrotados de hombres y mujeres, huían vertiginosamente. Los bares, los teatros, los restaurantes, tampoco eran los mismos. Turbas de gentes desarrapadas los invadían... (84-85). 
Sin embargo, la narradora quiere dejar constancia de la capacidad de adaptación del hombre al espacio y por ello señala que, aún y con la ciudad prácticamente destruida, la vida cotidiana no se interrumpe y los lugares habituales de diversión de antes de la guerra sobreviven con un aspecto desolado:

Aquella noche [...] fueron al Boston, un bar que en tiempos sería lujoso, en la calle Aribau. Lo frecuentaban ahora comisarios, carabineros, oficiales del C.A.S.E. Detrás del mostrador había un alto anaquel de madera tallada con las filigranas astilladas, y enmarcando espejos, ya opacos, como bañados por luz de gas (105).

En otros momentos el espacio indisociable del tiempo pasado, ahora detenido ya para siempre, adquiere un aspecto fantasmagórico, casi mágico, muy característico del estilo poético de Ana María Matute:

Tropezando, salieron del local. [...] Bajaron por la calle de Aribau hasta la plaza de la Universidad. El monumento al doctor Robert, de sólido granito y mármol entre la niebla húmeda, parecía un blanco cendal, diluido y flotante, detenido así, para siempre, en un aire milagrosamente quieto. La humedad mojaba el enlosado y el asfalto, y resbalaban alguna vez (107).

En todas estas descripciones el juego metonímico es constante. La ciudad vive al compás de los protagonistas:

En la calle, la ciudad ya estaba despierta. Gente desconocida iba a sus quehaceres.... Veía sus rostros ateridos de frío, sus ojos preocupados (108).

Sol recordó el tiempo en que creía en un mundo peligroso, pero no temido, como ahora, con las ciudades rotas, sucias, hambrientas, con innumerables seres inclinados al suelo para recoger desperdicios (112).

$\mathrm{Y}$ en ese desolado paisaje urbano surgen nuevos espacios como el comedor del auxilio social, resultado de la forzosa transformación de un antiguo restaurante: «El comedor al que acudía era un antiguo restaurante de la calle Muntaner. Las vidrieras y los espejos estaban materialmente cubiertos de carteles...» (129). Este nuevo espacio de supervivencia es un símbolo de la imparable transformación urbana que se ha operado en esta primera parte de la novela. De aquella ciudad soñada y construida por Sol con cuadernos en su pupitre escolar no queda ya nada. La ciudad se ha degradado bajo los constantes bombardeos. Ha enmudecido ante el forzoso desalojo de sus habitantes, que como topos se esconden ahora en los refugios subterráneos:

Todo vestigio de luz fue borrado temerosamente. Barcelona se apagaba, se escondía. El miedo amenazaba desde aquel cielo impávido, vigilante sin cesar. En los sótanos de la gran ciudad, el miedo se almacenaba codo con codo de cada hombre, de cada mujer, de cada niño (135). 


\section{CULMINACIÓN DEL PROCESO INICIÁTICO DE SOL Y VISIÓN APOCALÍPTICA DEL ESPACIO URBANO}

En esta segunda parte la visión de la ciudad de Barcelona, ya en plena guerra, es realmente apocalíptica. En el proceso iniciático de Sol el descubrimiento de la vida mísera de los amigos de su hermano ha resultado decisivo. Además se produce una simbiosis entre la proximidad de la muerte inexorable de Daniel, enfermo de tuberculosis, y el posterior bombardeo que destruye prácticamente la casa y la zona en la que vive junto a su padre, un pobre maestro de escuela cuya «máxima, tal vez única ambición, fue tener una pequeña biblioteca. Pero no la tuvo hasta que Pablo la requisó para él» (167). La descripción extraordinariamente sensorial del espacio aspira a reproducir verazmente las sensaciones que experimentan los personajes:

Cerca de las doce llegaron a la calle en que vivía Daniel, en una parte de la ciudad desconocida para Sol. Los altos muros de las casas se alzaban opacos y llenos de silencio. El olor del mar se adhería a ellos con un regusto de podredumbre. Le pareció que en el cielo, en el estrecho y largo cielo aprisionado, había un timbre lúgubre, como un presagio. Subieron la escalera en silencio. En lo alto había una claridad lechosa, más intensa cuanto más se acercaban a ella. (153).

Y como único elemento confortable en medio de tanta miseria el calor del humilde brasero, cuyas cenizas avivan de nuevo en la imaginación de Sol el recuerdo de otra ciudad ideal como las de antes de la guerra. El lenguaje se transforma a través de continuas imágenes y metáforas que refuerzan su carácter lírico y poético:

-Es una ciudad, como las de antes [...] Sí, era una ciudad grande, de noche, iluminada. Los dos -ella también, tal vez- oyeron hablar de una época despreocupada. Vieron revistas pasadas de moda, con fotografías. Calles, tiendas con escaparates llenos de objetos que la gente no precisaba escuetamente para vivir [...] Sol acercó una mano abierta al resplandor de aquella imaginaria ciudad, que se encendía y se apagaba continuamente [...] Si ese lugar no existía, era necesario crearlo, ser de los que amasan una época que no tuviese nada que ver con las ciudades encendidas ni con las ciudades que se esconden en la noche (160).

Otra constante en el tratamiento espacial de la novela es que aunque se describen diversos espacios interiores nunca se pierde la referencia al espacio exterior, urbano, de manera que la ciudad, no es sólo escenario sino protagonista del relato: «Desde las ventanas de la buhardilla se veía la aglomeración gris y rojiza de las azoteas y el humo, la ropa tendida y los palomares» (168-9), una aparente normalidad que iba a ser repentinamente destruida por los bombardeos. De nuevo Ana María Matute, en un alarde del dominio de los recursos 
poéticos del lenguaje, expresa la humanización de los objetos frente a la continua deshumanización del espacio y la angustia creciente de los seres que lo habitan. La descripción de las paredes de la buhardilla y de los sótanos-refugio simultáneamente a la descripción de los bombardeos es un buen ejemplo:

Las paredes parecían contagiadas de miedo y los objetos, hasta los más fríos e inanimados, cobraban una vibratilidad humana. De repente, hasta las ventanas de la buhardilla, llegó un soplo rojizo. Luego, tras un instante de silencio, estallaron dos bombas cerca de allí [...].

Se oían las descargas de los antiaéreos y el zumbar de los motores sobre la ciudad. A veces, la blanca caricia de un reflector, resbalando por la ventana, iluminaba fugazmente la habitación. Temblaban los cristales y un bronco y sordo rumor, como de voces perdidas, se alejaba formando una rara masa en el espacio. Lo que realmente le llenaba de angustia era la desnudez de aquellas paredes estrechas y llenas de humedad, el suelo desportillado, el frío total del cuarto de Daniel (173).

La casa tenía una de esas fachadas verde sucio que parecen gotear constantemente. Casi naciendo del suelo, se abrían las ventanas del sótano, protegidas con mohosas rejas, cuyos vidrios, salpicados de barro, apenas dejaban paso a la luz. Antes hubo en los sótanos una bodega, más tarde un almacén de granos y, últimamente, debido a su humedad, no se utilizaban más que para trastero, sirviendo también de refugio a los vecinos durante los bombardeos (178).

La minuciosa descripción de la destrucción de la humilde buhardilla en los alrededores de la vía Layetana por efecto de los continuos bombardeos es una experiencia traumática que Sol vive lejos de su hogar y que resulta determinante en su actitud de rebeldía ante la injusticia social y la pobreza, que era mucho más evidente en determinadas zonas de la ciudad:

La escalera se había hundido en su parte superior, y temblaban los ladrillos peligrosamente bajo sus pies. La buhardilla estaba destrozada. Grandes huecos en la pared dejaban ver el cielo, nada quedaba del descansillo, de aquella luz espectral y hermosa bajo la que estuvieron Sol y él minutos antes [...] La enorme herida de la buhardilla que ahora se ofrecía a sus ojos era de una tristeza vulgar, casi ridícula. «No hay derecho a descubrir de esta forma la miseria de la gente...» Era todo lo que se le ocurría, era lo único que pensaba en medio del frío (226).

$\mathrm{Y}$ tras los continuos bombardeos, el desescombro que deja al descubierto retazos de vida, recuerdos que sobreviven como por milagro, como el cuadro que colgaba todavía de una pared semi destruida. A partir de este momento, con la destrucción total del espacio familiar de la buhardilla y el suicidio de Pablo, tras resultar gravemente herido en el bombardeo, Sol acompañada de Cristián -el único superviviente de los tres hermanos-, inicia el ascenso hacia 
la parte alta de la ciudad, donde se refugiaran en una torre incautada a sus dueños por Pablo:

Iban ascendiendo ciudad arriba y Sol sintió una gran melancolía. Qué inexplicablemente dulce le parecía Barcelona, en suave declive, en su color, rosa y dorado, en aquel despertar, qué dulce y fuerte era el reflejo de su ciudad dentro de ella. Todo estaba aún como temblando a aquella hora. Una pared surgió, rota, negruzca, mirándoles por cien agujeros. Entre escombros, un cuadro, colgaba todavía del muro, parecía un milagro.

Caminaron calles y calles que les alejaron del mar. Tristes calles barridas en su intimidad, carteles rasgados en las fachadas de las casas. En las esquinas se amontonaban basuras y desechos. Cadenas de hombres se dedicaban al desescombro, entre las ruinas

- ¿Dónde es? -preguntó Sol.

-En Sarriá... (247).

A medida que ascienden hacia Sarriá Sol se siente mucho más identificada con aquella parte de la ciudad, que había sido el escenario de su infancia feliz antes de la guerra. Al contemplar la ciudad destruida y la miseria de las gentes, vuelven sobre ella con nitidez los recuerdos de la ciudad feliz de su infancia. Como en un fundido cinematográfico la mirada presente y la memoria del pasado se proyectan unidas:

A medida que ascendían Sol se familiarizaba con las calles y las anchas avenidas que le eran habituales, con sus árboles mutilados para hacer leña. No tardarían mucho en bajar de la montaña grupos de gente con brazadas de rama. El Tibidabo, alto y gris, recortaba su joroba grande, oscura, en la mañana. No parecía la misma montaña que viera de niña, desde los balcones de su casa $[\ldots]$

Sol recordó las hileras de luces en la noche, las raudas estelas luminosas reflejadas en el asfalto brillante. Eran las noches de sus esperadas vacaciones, pero ya no había vacaciones para ella. Qué distinta era esta ciudad despojada, cubierta de letreros rojos y verdes, negros, blancos, con signos de exclamación en todas las tapias, con toscos monumentos de cartón despellejados por la lluvia y el viento, con crujidos rítmicos de pisadas en el asfalto y voces de mando rompiendo el silencio de las plazas. Qué distinta aquella ciudad, recordada desde la blanca ausencia de Saint-Paul. Espléndida y luminosa, le dolía haberla soñado de otro modo a como ahora la veía: desmantelada, sucia, pobre, vencida por un enemigo que aún le parecía impreciso, pero cierto. Deseó reencontrar aquella belleza en su abandono como en su misma vida, y amarla con aquel dolor de manos vacías que hacía tiempo la abatía. Y se contempló a sí misma con una sonrisa: el vestido, estrecho y usado, sus viejas e inadecuadas sandalias veraniegas. Un viento duro, rojo de sangre y de tierra, había arrasado pasados y luces, todo parecía dormido o sumido en la muerte. «De ahora en adelante...», le pareció que murmuraba todo a su alrededor. Los escaparates vacíos, los cristales rotos, las gentes con ropas insuficientes, 
que apenas les cubrían los brazos, las ramas heridas de los árboles que caían, caían (248).

En este momento decisivo de la trama argumental cobra verdadero sentido el metafórico título y leiv-motif de la novela, Luciérnagas. Sol y Cristián son como dos «luciérnagas, barcos errantes en la noche» (252), que caminan unidos por el sufrimiento y la experiencia de la guerra como «criaturas errantes, dando tumbos, chocando contra los muros, la cabeza encendida, luciérnagas» (261).

\section{IV: EL REGRESO: YA NADA VOLVERÁ A SER IGUAL}

La tercera parte, el regreso de Sol a su casa se produce después convivir con Cristián durante algún tiempo en la torre de Sarria, donde serán detenidos y llevados a la cárcel modelo en la calle Entenza. Después de varios días en la cárcel Sol recupera la libertad y deambula por la ciudad en busca del mar en un nuevo intento por recuperar el espacio urbano de su infancia:

Al encontrarse en la calle entrecerró los ojos y se apoyó en un muro.

Miró turbadamente en derredor y reconoció la Vía Layetana. «Allá abajo está el mar», y un deseo de ir hacia él la llenó, vivificándola, como si la vista del mar de su infancia, de un tiempo lejano, fuese a devolverle aquella niña que

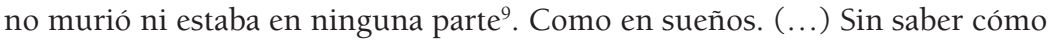
se encontró en la Barceloneta, entre paredes sucias o arruinadas, mujerucas trasegando extraños bultos, chiquillos que hurgaban en los escombros buscando tesoros inexistentes y luego, por fin el mar (275).

De nuevo la ciudad, como escenario de la vida presente y de la memoria pasada. La protagonista se siente ya inevitablemente ligada a aquellos espacios para siempre:

La Plaza de Cataluña, barrida por un viento que levantaba nubes de polvo, aparecía solitaria, como desnuda. Tiempo atrás, recordaba, en el centro había un monumento al soldado desconocido, en cartón piedra.... Mientras caminaba hacia su casa, se notaba tremendamente ajena a todo y, al propio tiempo, condenada a cuanto la rodeaba (277).

9. Es una idea recurrente en Matute: «Cuando miro mis fotografías de niña me parece descubrir en ellas un reproche, una protesta por lo que hice después con aquella niña. No es tranquilizador mirar el rostro del niño que fuimos, de los misteriosos niños que no murieron ni morirán y nadie sabe donde habitan, quizá en el perfume de una tarde, en la sombra de un árbol que se alza en la memoria» (Ana María Matute, «Una literatura amenazada», Magazin de la Vanguardia, Abril, 1997), y será uno de los ejes temáticos de sus mejores novelas desde Primera memoria a Paraíso inhabitado. 
Sin necesidad de precisar más la cronología la descripción nos sitúa en el mes de enero de 1939, con la toma de la ciudad por parte de las tropas del general Yagüe. Una ciudad extenuada, moribunda como muchos de sus habitantes cedía finalmente ante el cerco de los continuos bombardeos. Sol, mientras asciende hacia calles que le resultan mucho más familiares, percibe esa mezcla de miedo y esperanza, que late en el ambiente urbano como expresión de las diferentes expectativas de los dos bandos contendientes:

La ciudad se revolvía como en un último estertor, las gentes huían presurosas ante el avance del ejército de Franco, y en las calles se palpaba la pena y la angustia, mal veladas. Coches y camiones atiborrados con colchones atados en la trasera o en la baca, camiones que llevaban hombres, o los devolvían, en una polvorosa y confusa retirada. Franco avanzaba, avanzaba, y Sol lo supo por el clima miedoso, por un lado, y lleno de esperanzas por el otro, que se advertía en el corazón de la ciudad. Una febril agitación se advertía frente a los centros oficiales, en los rostros que se cruzaban en su camino. Junto a una fuente había una larga cola de personas, con garrafas, cántaros y jarras, en busca de agua.

Sol se alejó, con paso lento. Sus pies la conducían ciudad arriba, ciudad arriba, y buscarían, aunque ella no lo hubiese querido, sus calles familiares, sus árboles, su infancia. En algunas plazas se amontonaban papeles, libros, oficios medio quemados.....Una gran náusea la sacudió, desde lo más profundo de su ser, como si partiese del centro mismo de su vida. (278-279).

Y ya sólo queda la visión final de la ciudad sometida, silenciosa, vencida y casi desierta. Sol en una última imagen contempla el espolio de lo poco que ha resistido a la destrucción sistemática de los insistentes bombardeos:

En la calle Muntaner vio un grupo que avanzaba arrastrando sacos y cajones [...] Cerca de la Plaza de Adriano, en lo que antes fue un garaje, convertido ahora en almacén una turba violenta y silenciosa se apiñaba, saqueándolo. Los aviones volaban cada vez más bajos [...] En las calles grises, abandonadas bajo el débil sol de invierno, los golpes tenían un eco blando y la brutalidad parecía atenuada por el silencio. El día, apenas dorado, se extinguía en la noche que se acercaba, un viento suave.... Sol vio un grupo de chiquillos descalzos, astrosos y renegridos, provistos de largos ganchos. Todo era un destripar escombros, un febril hurgar entre la podredumbre y la miseria, en busca de lo que fuese (296).

\section{CONCLUSIÓN}

De lo dicho hasta aquí y de otros muchos pasajes que podrían citarse se desprende la relevante función que el espacio urbano ligado a un tiempo concreto, verdadero cronotopos, desempeña en la novela. El espacio es tan potente que en algunos momentos desplaza la atención del personaje, convirtiéndose 
en verdadero protagonista del relato. La visión caótica y apocalíptica de la ciudad de Barcelona es el escenario de Luciérnagas pero es también metáfora, metonimia y símbolo de los personajes.

Como en otras muchas novelas líricas de aprendizaje ${ }^{10}$, cuya pervivencia es rastreable en la actualidad, a través del espacio asistimos al proceso de transformación del personaje en un juego de reciprocidades que ya anunciamos al principio de este trabajo. De la misma manera que, a través de las vivencias de la protagonista, Ana María Matute ha dejado constancia de su experiencia personal, de sus recuerdos del pasado trágico de la guerra civil, del paisaje urbano y familiar de su infancia. Paisaje urbano que es fundamentalmente, como en el cine neorrealista italiano, mirada y memoria de un espacio y un tiempo concreto: Barcelona durante la guerra civil.

\section{BIBLIOGRAFÍA}

Abellán, Manuel, Censura y creación literaria en España (1939-1976), Barcelona, Península, 1980.

BAjTIN, Mijail, «Las formas del tiempo y del cronotopo en la novela» en Teoría y estética de la novela, Madrid, Taurus, 1989, pp. 237-410.

Bravo, $\mathrm{M}^{a}$ Elena, Faulkner en España. Perspectivas de la narrativa de postguerra, Barcelona, Península, 1985, pp.150.162.

CAMPBell, Joseph, El héroe de las mil caras, México, FCE, 1980 [1949]

CASTELlET, José María, Notas sobre literatura española contemporánea, Barcelona, Laye, 1955.

FreEDMAn, Ralph, La novela lírica. Herman Hesse, André Gide y Virginia Woolf, Barcelona, Barral, 1972 [1969]

FUENTE, Inmaculada de la, Mujeres de la postguerra, Barcelona, Planeta, 2002.

GARRIDO DomínGUEZ, Antonio, «El espacio», El texto narrativo, Madrid, Síntesis, 1993, pp.207-237.

Gullón, Ricardo, Espacio y novela, Barcelona, Bosch, 1980.

Gullón, Ricardo, La novela lírica, Madrid, Cátedra, 1984.

MATUte, Ana Maa, Prólogo General, Obras completas, Barcelona, Destino, 1971.

MATUte, Ana Mª Luciérnagas, Barcelona, Destino, 1993.

MATUTE, Ana $\mathrm{M}^{\mathrm{a}}$, «Una literatura amenazada», La Vanguardia (Magazín, Abril 1997).

MoRETTI, Franco, Il romanzo di formazione, Torino, Einaudi, 1999.

10. Sobre este aspecto véase el espléndido artículo de Ermitas Penas, «Vigencia de la novela de aprendizaje: Un análisis de Carreteras secundarias de Martínez de Pisón y El viento de la luna de Muñoz Molina», Anales de la Universidad de Alicante, 21, 2009: 117-141. 
PENAS, Ermitas, «Vigencia de la novela de aprendizaje: Un análisis de Carreteras secundarias de Martínez de Pisón y El viento de la luna de Muñoz Molina», Anales de la Universidad de Alicante, 21, 2009, pp.117-141.

RidDEL, $\mathrm{M}^{\mathrm{a}}$ del Carmen, La escritura femenina en la postguerra española. Nueva York, Peter Lang Publishing, 1995.

RODRÍGUEZ FONTELA, Ma Ángeles, La novela de autoformación, Kasel, Universidad de Oviedo-Reichenberger, 1996.

Roma, Rosa, Ana Ma Matute, Madrid, Epesa, «Grandes escritores contemporáneos», 1971.

SobejAno, Gonzalo, La novela española de nuestro tiempo, Madrid, Prensa Española, 1970, pp. 465-

SOTElo VÁzQUEZ, Marisa, «Primera memoria de Ana $\mathrm{M}^{\mathrm{a}}$ Matute, la vida es una infancia repetida», Salina, 13, 1999, pp. 171-178.

Vilanova, Antonio, «En esta tierra», «Ana Mª Matute: El mundo de la niñez durante la guerra civil o la corrupción de la inocencia», Novela y sociedad en la España de la postguerra, Barcelona, Lumen, 1995, pp.298-302.

Villanueva, Darío, Prólogo a La novela lírica, I, Madrid, Taurus, 1984, pp. 9-23.

Villanueva, Darío, El comentario de textos narrativos: La novela, Madrid, Ediciones Júcar, 1989.

Fecha de recepción: 8-1-2012

Fecha de aceptación: 30-5-2012 